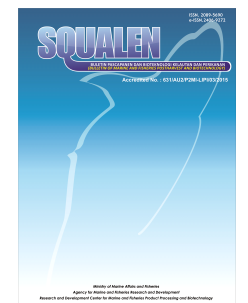

\title{
Growth Rate and Histamine Production of Klebsiella sp. CK02 Isolated from Skipjack Tuna Compared with Morganella morganii ATCC 25830 at Various Incubation Temperatures
}

\author{
Aldino Dityanawarman', Indun Dewi Puspita ${ }^{1 *}$, Susana Endah Ratnawati ${ }^{1}$, Nurfitri Ekantari ${ }^{1}$, and Mark Tamplin ${ }^{2}$ \\ ${ }^{1}$ Department of Fisheries, Faculty of Agriculture, Gadjah Mada University \\ Jalan Flora Bld. A4 Bulaksumur, Yogyakarta 55281, Indonesia \\ 2 Tasmanian Institute of Agriculture, Private Bag 54, Hobart, Tasmania 7001, Australia \\ Article history: \\ Received: 27 January 2020; Revised: 13 April 2020; Accepted: 20 April 2020
}

\begin{abstract}
One of an important quality parameter in tuna is the level of histamine content. The contamination of histamine in tuna is mainly due to the activity of histidine decarboxylase produced by the bacteria. A rapid growth of histamine producing bacteria is correlated with the practice of temperature abuse during handling. This study aimed to develop predictive growth modeling of two histamine-producing bacteria in the function of temperature. The growth and histamine production of Klebsiella sp. CK02 and Morganella morganii ATCC 25830 at various temperatures were measured in tryptic soy broth histidine (TSBH) and tuna fish infusion broth (TFIB) growth media. Broths were incubated at $4^{\circ} \mathrm{C}$ and $15^{\circ} \mathrm{C}$ for 7 days, and at $30^{\circ} \mathrm{C}$ and $40^{\circ} \mathrm{C}$ for 24 hours. The Baranyi and Roberts model was used with DMFit to determine primary growth kinectics, and the Ratkowsky square root model to describe bacterial growth rate as a function of temperature. Histamine production was enumerated by the apparent yield factor ( $\mathrm{pY}$ his/ $\mathrm{CFu})$ value. Growth rate increased with temperature, with a maximum rate at $40^{\circ} \mathrm{C}$ for Klebsiella sp. CK02 (0.740 log CFU/h) and M. morganii (0.578 log CFU/h). The $\mathrm{T}_{\text {min }}$ for Klebsiella sp. CK02 in TFIB was $-8.9^{\circ} \mathrm{C}$, indicating better survival in low storage temperature, compare to M. morganii ATCC 25830. In addition, Klebsiella sp. CK02 produced a lower $\mathrm{pY} \mathrm{Y}_{\text {his/CFU }}$ at 15 and $30^{\circ} \mathrm{C}$ compared to M. morganii ATCC 25830.
\end{abstract}

Keywords: growth rate, temperature, histamine, Klebsiella sp. CK02, M. morganii ATCC 25830

\section{Introduction}

Scombridae and Scomberesocidae fish commonly have a high concentration of the amino acid histidine (Rawles, Flick, \& Martin, 1996). During fish spoilage, bacteria can produce decarboxylase, an enzyme that converts free histidine and other amino acids into histamine and other biogenic amines, two substances frequently used as fish quality indicators (Lehane \& Olley, 2000), as well as food safety indicators due to the toxic effects of histamine (Sumner, Ross, \& Ababouch, 2004). Histamine-related toxication, known as histamine fish poisoning (HFP), is often associated with consumption of seafood (Rawles et al., 1996). Histamine production in fish is mainly caused by improper handling temperature, which causes the growth of histidine decarboxylase (HDC)-producing bacteria or histamine-producing bacteria (HPB) (Lehane \& Olley, 2000). Sumner et al. (2004) reported that common HPB are from the Enterobacteriaceae family, such as Hafnia, Klebsiella, and Morganella, as well as from the Bacillaceae family, with varied abilities of histamine production among species. Enterobacter aerogenes, Morganella morganii, Photobacterium damselae, Raoultella planticola, and $R$. ornithinolytica can produce $>1,000 \mathrm{ppm}$ histamine, whereas Citrobacter freundii, Escherichia coli, Hafnia alvei, and Vibrio alginolyticus generate low histamine levels of $<500 \mathrm{ppm}$, under similar culture conditions (Björnsdóttir-Butler, Bolton, Jaykus, McClellan-Green, \& Green, 2010). Among HPB species, H. alvei, Klebsiella pneumoniae, and $M$. morganii have been isolated from fish samples that allegedly caused scombroid poisoning (Rawles et al., 1996). Moreover,

${ }^{*}$ Corresponding author.

E-mail: indun_dp@ugm.ac.id 
M. psychrotolerance and P. phosphoreum that were most frequently detected in fresh yellowfin tuna fillets showed growth and histamine production at $4^{\circ} \mathrm{C}$ (Trevisani, Cecchini, Fedrizzi, Corradini, Mancusi, \& Tothill, 2019). The ability of M. psychrotolerance in producing histamine at low temperature shows that there is still a risk of histamine poisoning in fish during low temperature handling (Wang, Yamaki, Kawai, \& Yamazaki, 2020).

Low temperature handling plays a critically important role in fish quality control, particularly in preventing histamine production. Models to predict HPB growth (Jorgensen, Huss, \& Dalgaard, 2000; Emborg \& Dalgaard, 2008) may be used to predict the relationship between temperature, other environmental parameters and HPB growth, as well as histamine production. Such models may help the fishery industry and food safety supervisory agencies to estimate shelf-life, optimize storage conditions, and analyze histamine exposure assessment (Emborg, 2007).

HPB strains used in histamine prediction models are generally isolated from subtropical fish. Jorgensen et al. (2000) developed a biogenic amine prediction model, including histamine, using bacteria isolated from cold-smoked salmon in Norway, while Emborg \& Dalgaard (2008) constructed a growth model using $M$. morganii and M. psychrotolerans isolated from yellowfin tuna in Denmark. Previously, we isolated HPB strain Klebsiella sp. CK02 from the skipjack tuna caught in the tropical area of Sadeng Port of Yogyakarta, which showed high histamine production. However, characteristic of its growth kinetics and histamine production rate remain unknown.

Studies on histamine production by Klebsiella spp. are merely observing the histamine concentration over time overlooking its relation to temperature. An earlier study by Taylor, Guthertz, Leatherwood, \& Lieber (1979) reported K. pneumoniae incubated in tuna fish infusion broth (TFIB) for $7 \mathrm{~h}$ produced $19,900 \mathrm{nmol}$ histamine/ml (i.e. $442 \mathrm{mg}$ histamine/100 $\mathrm{g}$ tuna) at $32^{\circ} \mathrm{C}$. The highest concentration of histamine produced by $K$. oxytoca was $1,415 \mathrm{ppm}$ after $18 \mathrm{~h}$ at $37^{\circ} \mathrm{C}$ (López-Sabater, Rodríguez-Jerez, Hernández-Herrero, \& Mora-Ventura, 1996). Later research by Özoðul (2004) demonstrated that the highest biogenic amine production from K. pneumoniae NCMIB 673 was 3,416 $\mathrm{mg} / \mathrm{L}$ histamine at $37^{\circ} \mathrm{C}$, in histidine decarboxylase broth (HDB) incubated for $2 \mathrm{~d}$.

Several ASEAN countries are prominent tuna producers in the world. Located in tropical area, they face challenging environmental conditions of high and fluctuating temperatures during cold chain handling of fish, which can promote microbial growth. Therefore, this study was conducted to quantitatively assess the effect of temperature on growth and histamine production of Klebsiella sp. CK02 compared with $M$. morganii ATCC 25830, a known HPB. The resulting data and predictive model may be used to manage microbial risks of tropical fishery products.

\section{Materials and Methods}

\subsection{Bacterial Culture}

Klebsiella sp. CK02 was obtained from the culture collection of Fishery Product Quality and Safety Laboratory, Department of Fisheries, Faculty of Agriculture, Universitas Gadjah Mada, and was isolated from skipjack tuna in Sadeng Port, Yogyakarta. Culti-Loops ${ }^{\mathrm{TM}}$ Morganella morganii subsp. morganii ATCC ${ }^{\mathrm{TM}} 25830^{\mathrm{TM}}$ was purchased from Thermo Scientific $^{\text {TM }}$ (Germany). Both bacteria tested positive for the histamine-producing gene (hdc), based on the method of Takahashi, Kimura, Yoshikawa, \& Fujii (2003).

\subsection{Media}

Tryptic soy broth (TSB; Oxoid) was used to prepare the inoculum. Tryptic soy broth histidine (TSBH) and tuna fish infusion broth (TFIB) were prepared to analyze bacterial growth and histamine production, according to Taylor \& Woychik (1982) and Taylor et al. (1979), respectively. TSBH was prepared from $3 \%$ TSB fortifed with $1 \%$ histidine (Merck, Germany). TFIB was prepared by homogenization of skipjack tuna in twice its amount of water $(\mathrm{w} / \mathrm{w})$, followed by steaming at $100^{\circ} \mathrm{C}$ for $1 \mathrm{~h}$. After cooling, the boiled fish was filtered using Whatman filter paper No.1, and then $1 \%$ glucose was added and the media was sterilized. Tryptic soy agar (TSA; Oxoid) was used for bacterial enumeration.

\subsection{Analysis of Bacterial Growth and Histamine Production}

Klebsiella sp. CK02 and M. morganii ATCC 25830 inocula were prepared by inoculation of TSB, followed by $24 \mathrm{~h}$ incubation at $37^{\circ} \mathrm{C}$. One loop of each species was inoculated in $10 \mathrm{ml} \mathrm{TSBH}$ and $10 \mathrm{ml} \mathrm{TFIB}$, followed by incubation at $4,15,30$ and $40^{\circ} \mathrm{C}$. Samples incubated at 4 and $15^{\circ} \mathrm{C}$ were observed every $24 \mathrm{~h}$ for $168 \mathrm{~h}$, whereas those incubated at 30 and $40^{\circ} \mathrm{C}$ were observed every $3 \mathrm{~h}$ for $24 \mathrm{~h}$. At each sampling time, bacterial and histamine concentration were recorded. All treatments were conducted in duplicate.

For bacterial enumeration on TSA, $0.1 \mathrm{ml}$ of bacteria grown in TSBH and TFIB was serially diluted in $0.9 \mathrm{ml}$ Butterfield Phosphate Buffer (BPB), plated on TSA, 
and incubated at $37^{\circ} \mathrm{C}$ for $24 \mathrm{~h}$. Counts were converted to $\log \mathrm{CFU} / \mathrm{ml}$.

Histamine concentration in TSBH and TFIB media was determined by thin-layer chromatography (TLC) silica gel plates (60F254, Merck, Germany) based on the method of Bajc \& Gaènik (2009). Approximately $1.0 \mu \mathrm{l}$ sample or histamine standard solution was spotted on plates. Compound separation was performed in a chamber using methanol:ammonia $(20: 1, v / v)$ as the mobile phase. Plates were removed from the chamber, dried in an oven, and then sprayed with ninhydrin solution ( $300 \mathrm{mg}$ ninhydrin in $100 \mathrm{ml} n$ butanol, containing $3 \mathrm{ml}$ glacial acetic acid) for spot visualization. TLC plates were scanned, and spots processed using Photoshop to measure brightness. A mathematical equation produced from brightness level versus histamine standard concentrations (100$3,000 \mathrm{ppm}$ ) was used to convert sample brightness to histamine concentration (ppm).

\subsection{Data Analysis}

Bacterial growth data were plotted with incubation time to obtain growth curves for Klebsiella sp. CK02 and $M$. morganii using MS Excel, and then fitted with the Baranyi \& Roberts (1995) primary model, using DMFit (http://www.combase.cc), to measure bacterial growth kinetic parameters of lag time, growth rate $\left(\mu_{\max }\right)$ and maximum population density $\left(\mathrm{N}_{\max }\right)$. The secondary square root model of Ratkowsky, Olley, McMeekin, \& Ball (1982) was used to estimate $\mu_{\max }$ as a function of temperature as follows:

$$
\mu_{\max }=\left[\mathrm{b}\left(\mathrm{T}-\mathrm{T}_{\min }\right)\right]^{2}
$$

where $\mu_{\max }$ is the maximum growth rate $(\log \mathrm{CFU} / \mathrm{h}), \mathrm{T}$ the temperature $\left({ }^{\circ} \mathrm{C}\right), T_{\min }$ the extrapolated minimum growth temperature, and $b$ is a regression coefficient.

To measure accuracy of the Ratkowsky square root model, root mean square error (RMSE) was calculated:

$$
R M S E_{\text {model }}=\sqrt{\frac{\sum_{i=t}^{n}\left(\text { observed }_{i}-\text { fitted }_{i}\right)^{2}}{n}}
$$

with observed as the observed value, fitted as the prediction value, and $\mathrm{n}$ as the data number. Bacterial histamine production was calculated using the apparent yield factor $\left(\mathrm{p} Y_{\text {his/CFu }}\right)$, according to Jorgensen et al. (2000):

$$
p Y_{\text {his/cfu }}=-\log \left(\frac{H i s_{\text {final }}-H i s_{\text {initial }}}{N_{\text {final }}-N_{\text {initial }}}\right)
$$

with $\mathrm{His}_{\text {final }}$ and $\mathrm{His}_{\text {initial }}$ as the final and initial histamine concentration (ppm), respectively, and, $\mathrm{N}_{\text {final }}$ and $\mathrm{N}_{\text {initial }}$ as the final and initial bacterial number $(\mathrm{CFU} / \mathrm{ml})$, respectively. Jorgensen et al. (2000) used $\mathrm{p} Y_{\text {his/CFu }}$ to measure bacterial histamine production, with lower $\mathrm{p} Y_{\text {his/CFU }}$ indicating higher production ability.

\section{Results and Discussion}

\subsection{Effect of Temperature on Growth Rate of Klebsiella sp. CK02 and M. morganii ATCC 25830}

Both Klebsiella sp. CK02 and M. morganii ATCC 25830 grew from 4 to $40^{\circ} \mathrm{C}$ (Figure 1). In general, there was no significant lag phase. For Klebsiella sp. CK02, growth rates $\left(\mu_{\max }\right)$ in TSBH ranged from 0.008 to 0.740 $\log \mathrm{CFU} / \mathrm{h}$ at 4 and $40^{\circ} \mathrm{C}$, respectively (Table 1 ). In TFIB, $\mu_{\max }$ were 1.5 and 2.7 times lower at 30 and $40^{\circ} \mathrm{C}$, respectively. Compared to Klebsiella sp. CK02, $\mu_{\max }$ for M. morganii ATCC 25830 were more similar between TSBH and TFIB. However, $\mu_{\max }$ were 1.24 and 1.06 times higher in TFIB than $\mathrm{TSBH}$ at 30 and $40^{\circ} \mathrm{C}$, respectively. Overall, $\mathrm{N}_{\max }$ ranged from 7.2 to $8.4 \mathrm{log}$ $\mathrm{CFU} / \mathrm{ml}$, with the exception of Klebsiella sp. CK02 where $\mathrm{N}_{\max }$ was $5.5 \log \mathrm{CFU} / \mathrm{ml}$.

Within the genus of Klebsiella, K. pneumoniae and K. oxytoca are well-known for producing significant levels of histamine in fish (Taylor et al., 1979; LópezSabater et al., 1996). In present study, skipjack isolate Klebsiella sp. CK02 shows a significant increase in cell number at 15,30 , and $40^{\circ} \mathrm{C}$ (Figure $1 \mathrm{a}$ and $1 \mathrm{~b}$ ). Similar increase in cell number at the same temperature range has also been reported in Klebsiella pneumoniae. Behling \& Taylor (1982) showed that during the initial $6 \mathrm{~h}$ at $37^{\circ} \mathrm{C}$, bacterial numbers increased from 7 to 9 log CFU/ml, with lower numbers at lower temperatures $\left(30\right.$ and $\left.15^{\circ} \mathrm{C}\right)$. Interestingly, it was also reported that despite faster growth at $37^{\circ} \mathrm{C}$, the maximum density at $30^{\circ} \mathrm{C}$ was higher. Similar results were also observed in this study, in which the maximum $\left(\mathrm{N}_{\max }\right)$ and the final bacterial number $\left(\mathrm{N}_{\text {finaa }}\right)$ of Klebsiella sp. CK02 at $30^{\circ} \mathrm{C}$ were higher than those at $40^{\circ} \mathrm{C}$ in both media (Table 1). López-Sabater, Rodriguez-Jerez, Hernández-Herrero, \& Mora-Ventura (1994) also reported that the $K$. pneumoniae number incubated at $37^{\circ} \mathrm{C}$ for $18 \mathrm{~h}$ was $8.34 \log \mathrm{CFU} / \mathrm{ml}$, whereas Taylor et al. (1979) reported an increase in bacterial number of $1.74 \log \mathrm{CFU} / \mathrm{ml}$ at $32^{\circ} \mathrm{C}$ for $7 \mathrm{~h}$.

Klebsiella sp. CK02 $\mu_{\max }$ in TSBH medium tended to be higher than in TFIB at all temperatures (Table 1). As previously reported by Chen, Wei, Koburger, \& Marshall (1989) regarding the growth of $K$. pneumoniae and other HPB in four types of media with various Lhistidine and glucose levels, the histidine level clearly affected bacterial growth, whereas glucose levels provided inconsistent pattern in bacterial growth. Significant growth was observed for K. pneumoniae, $M$. morganii, and $K$. oxytoca in media with high histidine levels, but $H$. alvei showed a higher $\mu_{\max }$ in low histidine medium (Chen et al., 1989). 

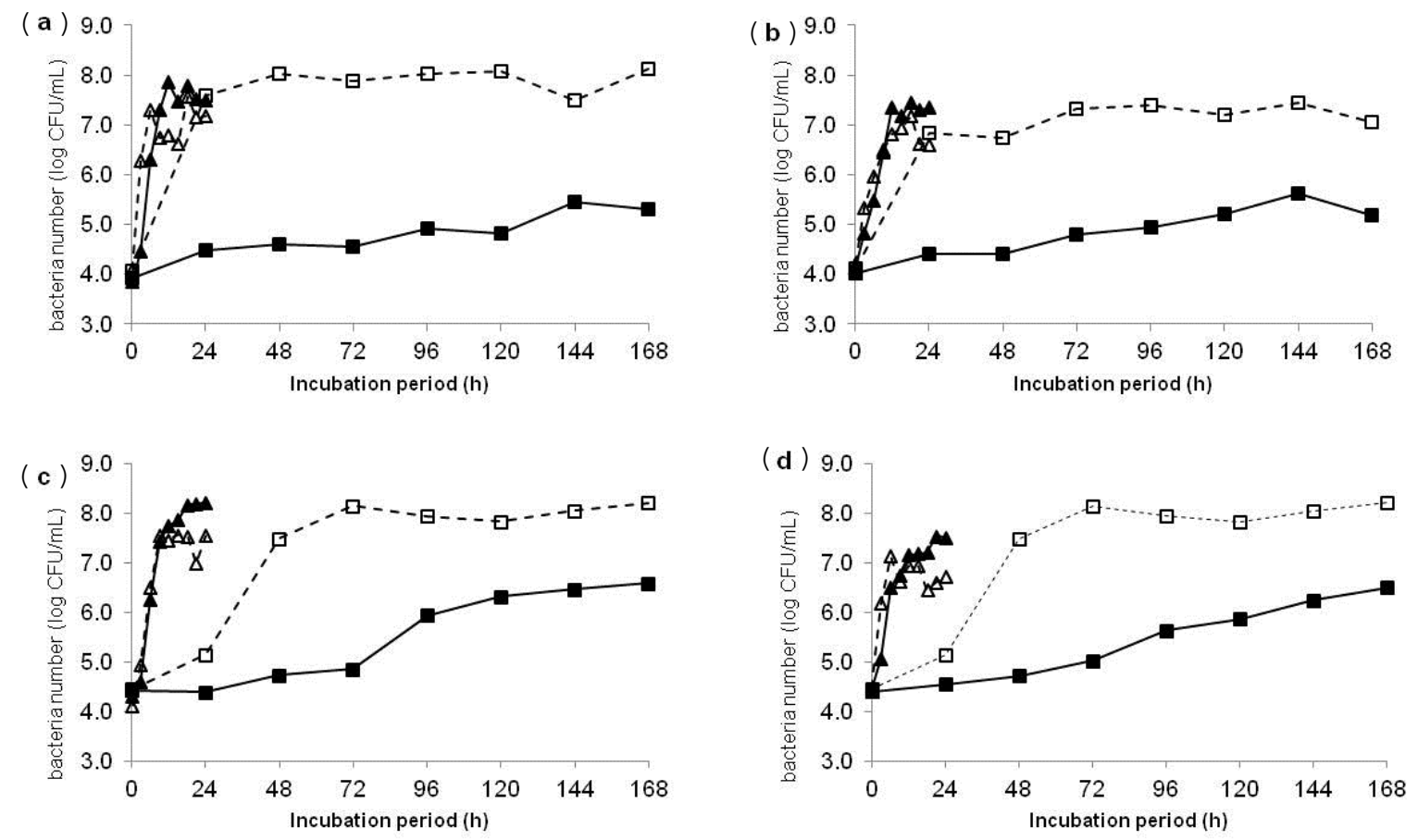

Figure 1. Klebsiella sp. CK02 (K) and Morganella morganii ATCC $25830(\mathrm{M})$ growth rate at $40^{\circ} \mathrm{C}(\triangle), 30^{\circ} \mathrm{C}$ $(\mathbf{\Delta}), 15^{\circ} \mathrm{C}(\square)$, and $4^{\circ} \mathrm{C}(\mathbf{\square})$. (a) $\mathrm{K}$ in TSBH; (b) $\mathrm{K}$ in TFIB; (c) $\mathrm{M}$ in TSBH; (d) $\mathrm{M}$ in TFIB.

Table 1. Klebsiella sp. CK02 and Morganella morganii ATCC 25830 growth rate at various incubation temperatures and media obtained using DMFit primary model

\begin{tabular}{|c|c|c|c|c|c|c|}
\hline Bacteria & $\begin{array}{l}\text { Temp. } \\
\left({ }^{\circ} \mathrm{C}\right)\end{array}$ & Medium & $\begin{array}{c}\mu_{\max } \\
(\log \mathrm{CFU} / \mathrm{h})^{\mathrm{a}}\end{array}$ & $\begin{array}{c}N_{\text {initial }} \\
(\log \mathrm{CFU} / \mathrm{ml})^{\mathrm{b}}\end{array}$ & $\begin{array}{c}\mathbf{N}_{\text {final }} \\
(\log \mathrm{CFU} / \mathrm{ml})^{\mathrm{b}}\end{array}$ & $\begin{array}{c}\mathbf{N}_{\max } \\
(\log \mathrm{CFU} / \mathrm{ml})^{\mathrm{b}}\end{array}$ \\
\hline \multirow[t]{8}{*}{ Klebsiella sp. CK02 } & 4 & TSBH & 0.008 & 4.1 & 5.4 & 5.5 \\
\hline & & TFIB & 0.008 & 4.1 & 5.6 & 5.7 \\
\hline & 15 & TSBH & 0.157 & 4.1 & 7.9 & 8.3 \\
\hline & & TFIB & 0.124 & 4.1 & 7.2 & 7.5 \\
\hline & 30 & TSBH & 0.43 & 3.6 & 7.6 & 8 \\
\hline & & TFIB & 0.274 & 4 & 7.4 & 7.4 \\
\hline & 40 & TSBH & 0.74 & 4.1 & 7 & 7.6 \\
\hline & & TFIB & 0.269 & 4.3 & 6.8 & 7.2 \\
\hline \multirow[t]{8}{*}{ M. morganii ATCC 25830} & 4 & TSBH & 0.022 & 4.2 & 6.6 & 7.6 \\
\hline & & TFIB & 0.018 & 4.4 & 6.5 & 6.9 \\
\hline & 15 & TSBH & 0.089 & 4.3 & 8 & 8.3 \\
\hline & & TFIB & 0.08 & 4.2 & 8 & 8.4 \\
\hline & 30 & TSBH & 0.359 & 4 & 8.1 & 8.3 \\
\hline & & TFIB & 0.444 & 4.5 & 7.4 & 7.6 \\
\hline & 40 & TSBH & 0.544 & 4.1 & 7.4 & 7.7 \\
\hline & & TFIB & 0.578 & 4.5 & 6.8 & 7.3 \\
\hline
\end{tabular}

Note :

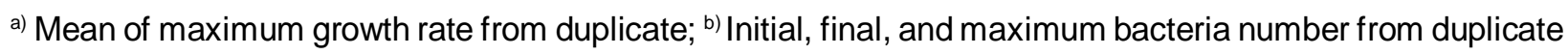


Table 2. Ratkowsky square root model for Klebsiella sp. CK02 and Morganella morganii ATCC 25830 growth rate in temperature function

\begin{tabular}{lccccc}
\hline \multicolumn{1}{c}{ Bacteria } & Medium & $\mathbf{T}_{\min }\left({ }^{\circ} \mathbf{C}\right)$ & b & RMSE & Prediction Model \\
\hline Klebsiella sp. CK02 & TSBH & -1.7 & 0.0209 & 0.021 & $\mu_{\max }=[0.0209(\mathrm{~T}+1.722)]^{2}$ \\
& TFIB & -8.9 & 0.0119 & 0.051 & $\mu_{\max }=[0.0119(\mathrm{~T}+8.889)]^{2}$ \\
M. morganii ATCC 25830 & TSBH & -4.1 & 0.0169 & 0.017 & $\mu_{\max }=[0.0169(\mathrm{~T}+4.053)]^{2}$ \\
& TFIB & -2.5 & 0.0184 & 0.048 & $\mu_{\max }=[0.0184(\mathrm{~T}+2.483)]^{2}$ \\
M. morganii DSM 14850 & Canned Tuna & 0.3 & 0.0331 & & \\
M. psychrotolerans JB T-11 & Canned Tuna & -7.5 & 0.021 & & \\
\hline
\end{tabular}

a) Emborg \& Dalgaard (2008)
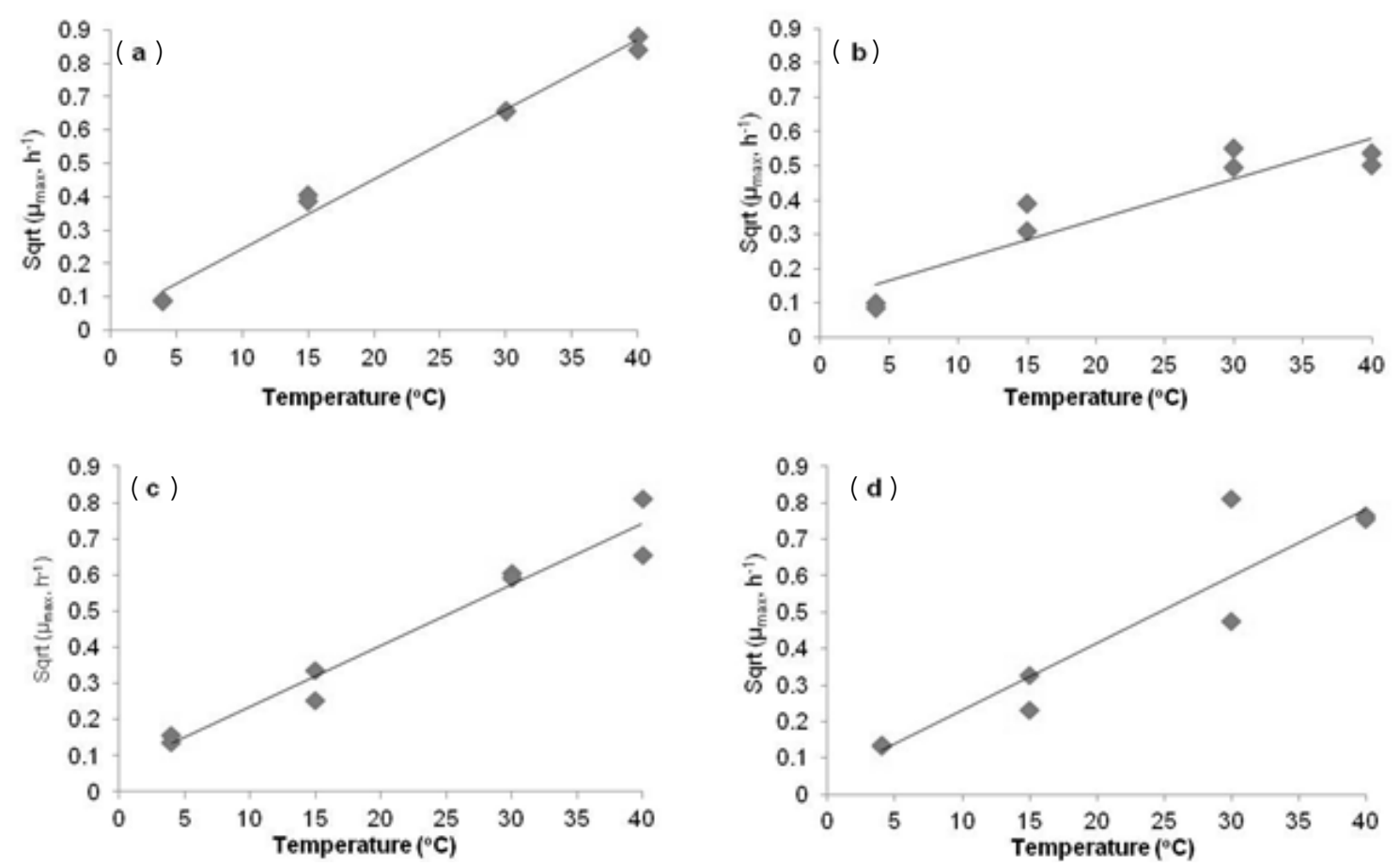

Figure 2. Correlation of temperature and growth rate of Klebsiella sp. CKO2 (K) and Morganella morganii ATCC 25830 (M) in the Ratkowsky square root model. (a) K in TSBH; (b) K in TFIB; (c) M in TSBH; (d) $M$ in TFIB

In contrast to Klebsiella sp. CK02 $\mu_{\max }$, that of $M$. morganii ATCC 25830 in TFIB was higher than in TSBH, especially as temperature increased (Table 1). Kim, Ben-Gigirey, Barros-Velázquez, Price, \& An (2000) reported higher M. morganii $\mu_{\max }$ in TFIB at $37^{\circ} \mathrm{C}$ than at 15 and $25^{\circ} \mathrm{C}$, with a high $\mathrm{N}_{\max }$ of $8 \log \mathrm{CFU} / \mathrm{ml}$ on day-1, whereas the highest cell numbers at $25^{\circ} \mathrm{C}$ and $15^{\circ} \mathrm{C}$ were observed on day-2 and day-3, respectively. Another study by Torres, Roeckel, \& Cristina (2002) regarding $M$. morganii growth in TSBH at 10, 15, 20 and $30^{\circ} \mathrm{C}$ reported that $\mu_{\max }$ increased with increasing temperature. At $30^{\circ} \mathrm{C}, \mu_{\max }$ reached the highest level of $0.8 \log \mathrm{CFU} / \mathrm{h}$.

Cell numbers of Klebsiella sp. CK02 and M. morganii ATCC 25830 showed a significant increase at $15^{\circ} \mathrm{C}$ in both media, but the rate appeared to be slower than that at $30^{\circ} \mathrm{C}$ and $40^{\circ} \mathrm{C}$ (Figure 1). The primary model analysis using DMFit also showed that the $\mu_{\max }$ of Klebsiella sp. CK02 tended to be higher at $15^{\circ} \mathrm{C}$ than that of $M$. morganii ATCC 25830 in both TSBH and TFIB media (Table 1). Behling \& Taylor (1982) also reported that K. pneumoniae exhibited 

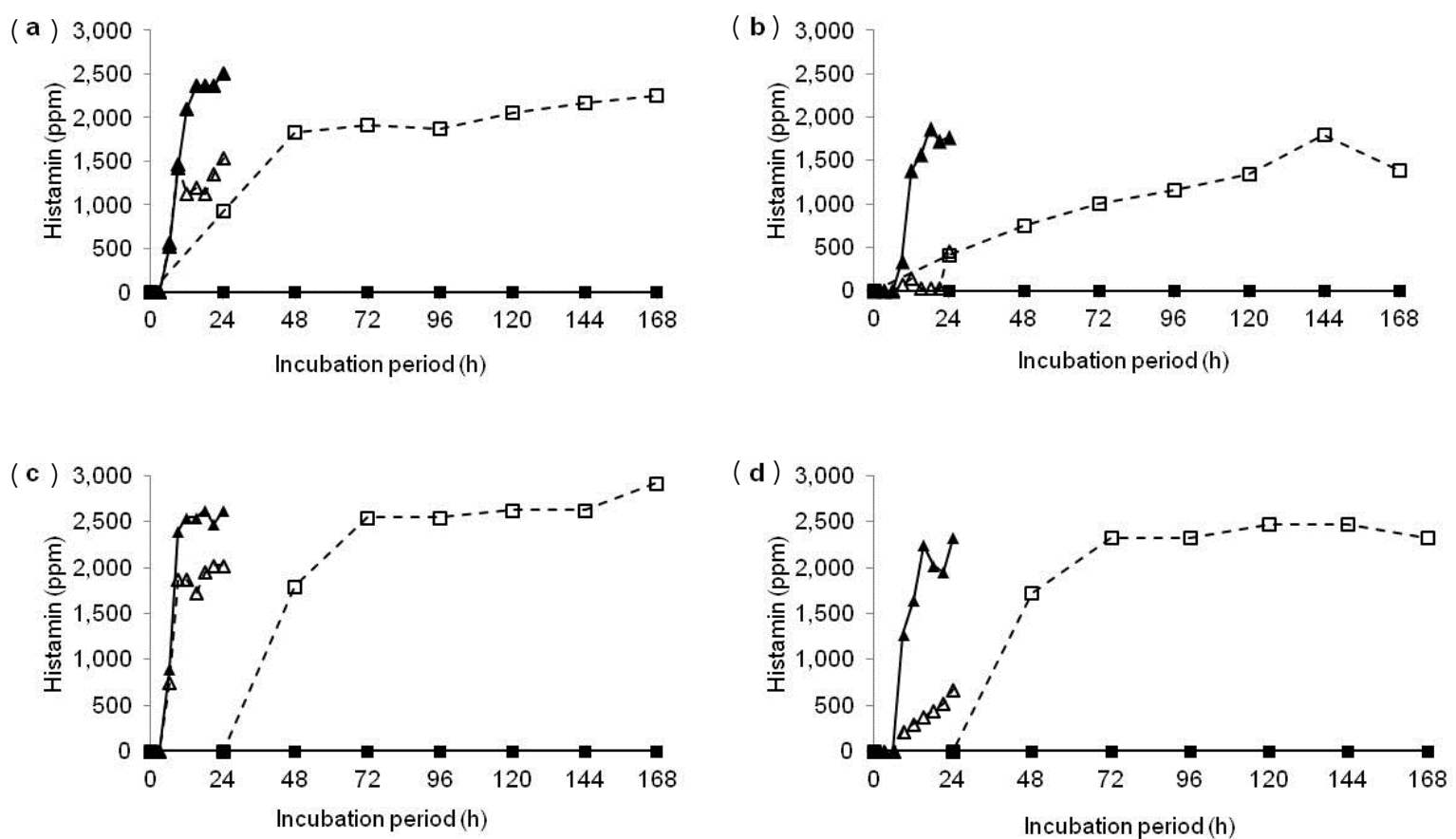

Figure 3. Histamine formation of Klebsiella sp. CK02 (K) and Morganella morganii ATCC $25830(\mathrm{M})$ at $40^{\circ} \mathrm{C}$ $(\triangle), 30^{\circ} \mathrm{C}(\mathbf{\Delta}), 15^{\circ} \mathrm{C}(\square)$, and $4^{\circ} \mathrm{C}(\mathbf{\square})$. (a) $\mathrm{K}$ in TSBH; (b) $\mathrm{K}$ in TFIB; (c) M in TSBH; (d) M in TFIB

Table 3. Apparent yield factor of histamine produced by Klebsiella sp. CK02 and Morganella morganii ATCC 25830 compared to other bacteria

\begin{tabular}{|c|c|c|c|c|}
\hline Bacteria & Temp $\left({ }^{\circ} \mathrm{C}\right)$ & Time (h) & Medium & 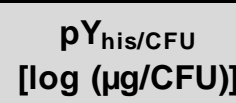 \\
\hline \multirow[t]{6}{*}{ Klebsiella sp. CK02 } & 15 & 168 & TSBH & 4.8 \\
\hline & 15 & 168 & TFIB & 4.1 \\
\hline & 30 & 24 & TSBH & 4.3 \\
\hline & 30 & 24 & TFIB & 4.1 \\
\hline & 40 & 24 & TSBH & 4.8 \\
\hline & 40 & 24 & TFIB & 4 \\
\hline \multirow[t]{6}{*}{ M. morganii ATCC 25830} & 15 & 168 & TSBH & 4.9 \\
\hline & 15 & 168 & TFIB & 5.1 \\
\hline & 30 & 24 & TSBH & 4.7 \\
\hline & 30 & 24 & TFIB & 4.3 \\
\hline & 40 & 24 & TSBH & 4.3 \\
\hline & 40 & 24 & TFIB & 4.2 \\
\hline \multirow[t]{2}{*}{$\overline{\text { K. pneumoniae }}{ }^{\mathrm{a})}$} & 10 & 48 & TFIB & 5.8 \\
\hline & 20 & 24 & TFIB & 5.9 \\
\hline \multirow[t]{2}{*}{$\overline{\text { K. oxytoca }}{ }^{a)}$} & 8 & 84 & Tuna & 4.3 \\
\hline & 20 & 18 & Tuna & 4.8 \\
\hline \multirow[t]{4}{*}{$\overline{M .}$ morganii ${ }^{\mathrm{a})}$} & 10 & 168 & TFIB & 5.8 \\
\hline & 12 & 240 & TSBH & 4.7 \\
\hline & 20 & 96 & TFIB & 5.9 \\
\hline & 20 & 120 & TSBH & 5.2 \\
\hline
\end{tabular}

Note: a) Emborg (2007) as calculated from other researches on several histamine-producing bacteria 
increasing $\mu_{\max }$ at $15^{\circ} \mathrm{C}$ from 7 to approximately 9 log $\mathrm{CFU} / \mathrm{ml}$ during $72 \mathrm{~h}$ of incubation. Similarly, Kim et al. (2000) also reported that $M$. morganii in TFIB at $15^{\circ} \mathrm{C}$ increased from 1.5 to $6.5 \mathrm{log} \mathrm{CFU} / \mathrm{ml}$ at $48 \mathrm{~h}$, and then entered the stationary phase at $8 \log$ CFU/ $\mathrm{ml}$. Conversely, Torres et al. (2002) reported a lower $\mu_{\max }$ for $M$. morganii at $15^{\circ} \mathrm{C}(0.2 \log \mathrm{CFU} / \mathrm{h})$ than at 20 and $30^{\circ} \mathrm{C}$.

At $4^{\circ} \mathrm{C}$, M. morganii ATCC 25830 showed a higher $\mu_{\max }$ than Klebsiella sp. CK02 (Table 1). This was different to that reported by Kim et al. (2000), who observed no noticeable $\mu_{\max }$ of M. morganiiOSL36 at $4^{\circ} \mathrm{C}$ for up to 5 days. Emborg \& Dalgaard (2008) reported that the minimum growth temperature for a mixture of $M$. morganii strains was $2.8^{\circ} \mathrm{C}$.

Growth rates were modelled as a function of temperature using the Ratkowsky square root model. The models for Klebsiella sp. CK02 were $y=0.0209 x$ +0.036 in TSBH $\left(R^{2}=0.9887\right)$ and $y=0.0119 x+0.1059$ in TFIB $\left(R^{2}=0.8525\right)$ (Table 2, Figure 2). For $M$. morganii ATCC 25830 they were $y=0.0169 x+0.0685$ in TSBH $\left(R^{2}=0.9579\right)$ and $y=0.0184 x+0.0457$ in TFIB $\left(R^{2}=0.8787\right)$ (Table 2, Figure 2). The predicted $\mathrm{T}_{\text {min }}$ of Klebsiella sp. CK02 in TFIB was lowest compared to other treatments (Table 2).

The Ratkowsky square root model was used to describe the relationship between temperature and sqrt $\mu_{\max }$ (Ratkowsky et al. 1982). The obtained mathematical model indicated a higher sqrt $\mu_{\max }$ with increasing temperature (Figure 2). Emborg \& Dalgaard (2008) also reported that $M$. morganii showed a higher sqrt $\mu_{\max }$ with increasing temperature up to $40^{\circ} \mathrm{C}$, but it decreased at $45^{\circ} \mathrm{C}$; however, the sqrt $\mu_{\max }$ for Klebsiella spp. have not yet been reported. The Ratkowsky square root model for Klebsiella sp. CK02 and M. morganii ATCC $25830 \mu_{\max }$ in temperature function (Table 2) represented $\mathrm{T}_{\min }$, the theoretical minimum temperature for bacterial growth. A lower $T_{\text {min }}$ represents a theoretical lower temperature at which bacterial growth ceases. Klebsiella sp. CK02 grown in TFIB showed the lowest $\mathrm{T}_{\text {min }}$ (Table 2), which indicates Klebsiella sp. CK02 ability to grow at low temperature. Behling and Taylor (1982) reported $K$. pneumoniae grew from 7 to $8 \log \mathrm{CFU} / \mathrm{ml}$ at $7^{\circ} \mathrm{C}$ at $72 \mathrm{~h}$, whereas no noticeable growth was detected at $0^{\circ} \mathrm{C}$ and $-3^{\circ} \mathrm{C}$. In TFIB, Klebsiella sp. CK02 exhibited higher ability to grow at low temperature than $M$. morganii ATCC 25830 . The $\mathrm{T}_{\min }$ of $M$. morganii ATCC 25830 reflects its ability to grow at low temperatures, but the value obtained in this study was lower than that of M. morganii DSM 14850 reported by Emborg and Dalgaard (2008). They reported the $T_{\min }$ of Morganella varied based on type and strain, with $M$. psychrotolerans tending to persist at low temperatures compared with M. morganii (Table 2).

\subsection{Effect of Temperature on Histamine Production by Klebsiella sp. CK02 and M. morganii ATCC 25830}

The histamine production rates of Klebsiella sp. CK02 and M. morganii ATCC 25830 in TSBH and TFIB were relatively high at 40,30 and $15^{\circ} \mathrm{C}$ (Figure 3). However, at $4^{\circ} \mathrm{C}$, no histamine production was detected, although growth was observed at a relatively low rate of $0.008-0.022 \log \mathrm{CFU} / \mathrm{h}$, with an associated cell number increase of 1.3-2.4 log CFU/ml until $\mathrm{N}_{\max }$ (Table 1). In TSBH, the highest histamine production by Klebsiella sp. CK02 was observed at $30^{\circ} \mathrm{C}$, ranging from $519 \mathrm{ppm}$ at $6 \mathrm{~h}$ to $2,098 \mathrm{ppm}$ at $12 \mathrm{~h}$ (Figure 3a), with a lower histamine production of $1,120 \mathrm{ppm}$ at $40^{\circ} \mathrm{C}$ during $12 \mathrm{~h}$ of incubation. Histamine production was also observed at $15^{\circ} \mathrm{C}$ but at a longer time period than that at $30^{\circ} \mathrm{C}$ and $40^{\circ} \mathrm{C}$, which was $2,060 \mathrm{ppm}$ after $120 \mathrm{~h}$. A similar histamine production pattern was also observed in TFIB, at a lower rate than that in TSBH. After $12 \mathrm{~h}$, the histamine production in TFIB was significantly higher at $30^{\circ} \mathrm{C}$ than at $40^{\circ} \mathrm{C}$, i.e., 1,384 versus $143 \mathrm{ppm}$, respectively (Figure 3b). At $15^{\circ} \mathrm{C}, 1,345 \mathrm{ppm}$ of histamine was produced after $120 \mathrm{~h}$.

The histamine production pattern of $M$. morganii ATCC 25830 was similar to that of Klebsiella sp. CK02, with a higher production rate at $30^{\circ} \mathrm{C}$ than at $40^{\circ} \mathrm{C}$. After $12 \mathrm{~h}$ of incubation in TSBH, 2,549 ppm of histamine was produced at $30^{\circ} \mathrm{C}$, which was significantly higher than $1,872 \mathrm{ppm}$ at $40^{\circ} \mathrm{C}$ (Figure 3c). Similarly, during the same incubation period in TFIB, 1,647 and $293 \mathrm{ppm}$ of histamine were produced at 30 and $40^{\circ} \mathrm{C}$, respectively (Figure $3 \mathrm{~d}$ ). Histamine production at $15^{\circ} \mathrm{C}$ started at $48 \mathrm{~h}$, with levels of 1,797 ppm in TSBH (Figure 3c) and 1,722 ppm in TFIB (Figure 3d).

The higher histamine production by K. pneumoniae and $M$. morganii at $30^{\circ} \mathrm{C}$ than at higher temperatures were reported. Behling \& Taylor (1982) showed a maximum histamine level of $40.8 \mu \mathrm{moles} / \mathrm{ml}$, or approximately $800 \mathrm{ppm}$, was produced by $K$. pneumoniae in TFIB after $72 \mathrm{~h}$ at $30^{\circ} \mathrm{C}$, which was much higher than at $37^{\circ} \mathrm{C}$ (i.e. $33 \mu \mathrm{moles} / \mathrm{ml}$ or approximately $660 \mathrm{ppm}$ ). Taylor et al. (1979) reported that $K$. pneumoniae incubated at $32^{\circ} \mathrm{C}$ in TFIB produced 4,420 ppm histamine at $7 \mathrm{~h}$. Histamine production by $K$. pneumoniae at low temperature was reported by Behling \& Taylor (1982). At $7^{\circ} \mathrm{C}, 14 \mu \mathrm{moles} /$ $\mathrm{ml}$ (approximately $280 \mathrm{ppm}$ histamine) was produced after $72 \mathrm{~h}$, whereas at $0^{\circ} \mathrm{C}$ and $-3^{\circ} \mathrm{C}$, no histamine was detected. In M. morganii, Kim et al. (2000) reported that after $24 \mathrm{~h}, 2,000 \mathrm{ppm}$ of histamine was produced in TFIB at $25^{\circ} \mathrm{C}$, which was double the value at $37^{\circ} \mathrm{C}$. Behling \& Taylor (1982) also reported that 
after $72 \mathrm{~h}$ of incubation, the optimum temperature for histamine production was $30^{\circ} \mathrm{C}$ for $M$. morganii 110SC2, K. pneumoniae, and $\mathrm{H}$. alvei, and $37^{\circ} \mathrm{C}$ for $E$. coli and C. freundii. Özoðul (2004) reported that the highest production of biogenic amines after $2 \mathrm{~d}$ of incubation of $M$. morganii and $K$. pneumoniae in HDB at $37^{\circ} \mathrm{C}$ was 4,038 and $3,416 \mathrm{mg} / \mathrm{L}$ of histamine, respectively. $M$. morganii also reportedly produced $2,000 \mathrm{ppm}$ of histamine at $15^{\circ} \mathrm{C}$ in TFIB after $48 \mathrm{~h}$ of incubation (Kim et al. 2000).

The results of this study indicate that the highest histamine production does not necessarily occur at the temperature associated with the highest $\mu_{\max }$. Specifically, Klebsiella sp. CK02 and M. morganii ATCC 25830 showed the highest histamine production at $30^{\circ} \mathrm{C}$ (Figure 3), whereas the highest $\mu_{\max }$ was at $40^{\circ} \mathrm{C}$ (Table 1). A similar result was also reported for Photobacterium phosphoreum YS4-7, psychrotrophic bacteria isolated from Japanese fish, Iwashi maruboshi, which showed the highest $\mu_{\max }$ at $27^{\circ} \mathrm{C}$, but significantly higher histamine production at $20^{\circ} \mathrm{C}$ (Kanki, Yoda, Ishibasi, \& Tsukamoto, 2004). This result was probably caused by the difference in the optimum temperature for HDC activity and bacterial growth. Kanki, Yoda, Tsukamoto, \& Baba (2007) reported varied optimum temperature and temperature stability of recombinant HDC activity from several HPB strains. This study also demonstrated higher histamine production by Klebsiella sp. CK02 and M. morganii ATCC 25830 in TSBH than in TFIB, which was probably caused by differences in histidine availability. Histidine acts as a substrate for HDC enzyme, as well as an inducer. The higher concentration of histidine in the medium increases the production of bacterial histamine as reported by Chen et al. (1989) in $K$. pneumonia and $M$. morganii that produced higher histamine levels in medium containing $2.7 \% \mathrm{~L}$ histidine than in $1 \%$ L-histidine.

In TLC analysis, histamine production by Klebsiella sp. CK02 and M. morganii ATCC 25830 in TSBH and TFIB at $4{ }^{\circ} \mathrm{C}$ was not detected, arguably due to the low production below $50 \mathrm{ppm}$ and the low sensitivity of the TLC method. Moreover, the absence of an apparent increase in histamine production until the final observation stage at $4^{\circ} \mathrm{C}$ was probably due to the low HDC activity at low temperature. Kim et al. (2000) reported that histamine production by $M$. morganii OSL 36 at $4^{\circ} \mathrm{C}$ for up to 2 weeks can be negligible, although there was only $5 \mathrm{~d}$ of observation. Kanki et al. (2004) reported that M. morganiiJCM 1672 incubated in $\mathrm{TSBH}$ at $20^{\circ} \mathrm{C}$ for $72 \mathrm{~h}$ produced 6,000 ppm of histamine, but it significantly decreased at $12^{\circ} \mathrm{C}$, with no histamine being detected at $4^{\circ} \mathrm{C}$. Kanki et al. (2007) reported $90 \%$ of histidine decarboxylase enzyme activity of $M$. morganii $\mathrm{JCM} 1672$ at $30^{\circ} \mathrm{C}$, which significantly decreased to $10 \%$ at $5^{\circ} \mathrm{C}$.

Histamine production by bacteria can also be measured by the apparent yield factor $\left(\mathrm{pY}_{\text {his//Fu }}\right)$, which represents the minimum bacterial number needed to produce detectable histamine. A lower $\mathrm{pY}_{\text {his/CFu }}$ value indicates higher histamine production (Jorgensen et al., 2000). The $\mathrm{pY}_{\text {his/CFu }}$ of Klebsiella sp. CK02 at 15$40^{\circ} \mathrm{C}$ in TSBH and TFIB ranged at 4.0-4.8 log $(\mu \mathrm{g} /$ $\mathrm{CFU}$ ( Table 3). The highest $\mathrm{pY}_{\text {his/CFU }}$ of Klebsiella sp. $\mathrm{CK} 02$ of $4.0 \mathrm{log}(\mu \mathrm{g} / \mathrm{CFU})$ was observed in TFIB at $40^{\circ} \mathrm{C}$, whereas that of $M$. morganii ATCC 25830 was slightly lower at 4.2-5.1 log $(\mu \mathrm{g} / \mathrm{CFU})$. The results of $\mathrm{pY}$ his/CFu value obtained from Klebsiella sp. CK02 and M. morganii ATCC 25830 were comparable with those of K. pneumoniae, K. oxytoca, and M. morganii reported by Emborg (2007). Prominently, Klebsiella sp. CK02 was able to produce higher histamine level in TFIB at $15^{\circ} \mathrm{C}$ compare to M. morganii ATCC 25830 , as shown by a lower $\mathrm{pY}_{\text {his/CFu }}$ (Table 3). This result indicates a higher possibility of histamine production when Klebsiella sp. contaminated fish experienced temperature abuse during handling.

\section{Conclusion}

This study demonstrated that temperature affected growth rate and histamine production of Klebsiella sp. CK02, with the highest $\mu_{\max }$ obtained at different temperatures than for optimum histamine production. Furthermore, histamine production by Klebsiella sp. CK02 varied at different temperatures and media. Klebsiella sp. CK02 has the potential to grow and produce histamine from $15-40^{\circ} \mathrm{C}$ and exhibited growth potential at lower temperature. Moreover, this study shows that Klebsiella sp. CK02 had a higher ability compare to M. morganii, a well-known histamine producing bacteria, to grow and produce histamine at $15^{\circ} \mathrm{C}$ in TFIB, a medium which nutrient content close to fish tissue. At temperature fluctuations during fish handling, Klebsiella sp. CK02 is able to grow despite sometimes insignificant histamine production. These findings indicate the importance of maintaining low temperature and short periods when handling fresh skipjack tuna to control growth of HPB and production of histamine. Further development of models is needed to predict the recommended temperature and the handling time period for quality and safety assurance of tropical fresh skipjack tuna.

\section{Acknowledgment}

This research was financially supported by the Ministry of Research, Technology, and Higher 
Education (KEMENRISTEK-DIKTI) year 2017/2018. Special thanks to Dr Triyanto for the suggestion of bacterial isolate identification.

\section{References}

Bajc, Z. \& Gaènik, K. (2009). Densitometric TLC analysis of histamine in fish and fishery products. J. Planar. Chromatogr. - Mod. TLC, 22(1), 15-17. doi:10.1556/ JPC.22.2009.1.3.

Baranyi, J. \& Roberts, T.A. (1995). Mathematics of predictive food microbiology. Int. J. Food Microbiol., 26(2), 199-218. doi:10.1016/0168-1605(94)00121$\mathrm{L}$.

Behling, A.R \& Taylor, S.L. (1982). Bacterial histamine production as a function of temperature and time of incubation. J. Food Sci., 47(4), 1311-1314. doi:10.1111/j.1365-2621.1982.tb07675.x.

Björnsdóttir-Butler, K., Bolton, G.E., Jaykus, L.-A., McClellan-Green, P.D., \& Green, D.P. (2010). Development of molecular-based methods for determination of high histamine producing bacteria in fish. Int. J. Food Microbiol., 139(3), 161-167. doi:10.1016/J.IJFOODMICRO.2010.03.017.

Chen, C.-M., Wei, C.I., Koburger, J.A., \& Marshall, M.R. (1989). Comparison of four agar media for detection of histamine-producing bacteria in tuna. J. Food Prot., 52(11), 808-813. doi:10.4315/0362-028X-52.11.808.

Emborg, J. (2007). Morganella psychrotolerans Identification, histamine formation and importance for histamine fish poisoning [PhD Thesis]. [Denmark]: Danish Institute for Fisheries Research.

Emborg, J. \& Dalgaard, P. (2008). Growth, inactivation and histamine formation of Morganella psychrotolerans and Morganella morganii development and evaluation of predictive models. Int. J. Food Microbiol., 128(2), 234-243. doi:10.1016/ J.IJFOODMICRO.2008.08.015.

Jorgensen, L.V., Huss, H.H., \& Dalgaard, P. (2000). The effect of biogenic amine production by single bacterial cultures and metabiosis on cold-smoked salmon. J. Appl. Microbiol., 89(6), 920-934. doi:10.1046/j.13652672.2000.01196.x.

Kanki, M., Yoda, T., Ishibashi, M., \& Tsukamoto, T. (2004). Photobacterium phosphoreum caused a histamine fish poisoning incident. Int. J. Food Microbiol., 92(1), 79-87. doi:10.1016/J.IJFOODMICRO.2003.08.019.

Kanki, M., Yoda, T., Tsukamoto, T., \& Baba, E. (2007). Histidine decarboxylases and their role in accumulation of histamine in tuna and dried saury. Appl. Environ. Microbiol., 73(5), 1467-73. doi:10.1128/AEM.01907-06.

Kim, S.-H., Ben-Gigirey, B., Barros-Velázquez, J., Price, R.J., \& An, H. (2000). Histamine and biogenic amine production by Morganella morganii isolated from temperature-abused albacore. J. Food Prot., 63(2), 244-251. doi:10.4315/0362-028X-63.2.244.
Lehane, L. \& Olley, J. (2000). Histamine fish poisoning revisited. Int. J. Food Microbiol., 58(1-2), 1-37. doi:10.1016/S0168-1605(00)00296-8.

López-Sabater, E.I., Rodríguez-Jerez, J., HernándezHerrero, M., \& Mora-Ventura, M.T. (1996). Incidence of histamine-forming bacteria and histamine content in scombroid fish species from retail markets in the Barcelona area. Int. J. Food Microbiol., 28(3), 411418. doi:10.1016/0168-1605(94)00007-7.

López-Sabater, E.I., Rodriguez-Jerez, J., HernándezHerrero, M., \& Mora-Ventura, M.T. (1994). Evaluation of histidine decarboxylase activity of bacteria isolated from sardine (Sardina pilchardus) by an enzymic method. Lett. Appl. Microbiol. 19(2), 70-75. doi:10.1111/j.1472-765X.1994.tb00908.x.

Özoðul, F. (2004). Production of biogenic amines by Morganella morganii, Klebsiella pneumoniae and Hafnia alvei using a rapid HPLC method. Eur. Food. Res. Technol., 219(5), 465-469. doi:10.1007/s00217004-0988-0.

Ratkowsky, D.A., Olley, J., McMeekin, T.A., \& Ball, A. (1982). Relationship between temperature and growth rate of bacterial cultures. J. Bacteriol., 149(1), 1-5.

Rawles, D.D., Flick, G.J., \& Martin, R.E. (1996). Biogenic amines in fish and shellfish. Adv. Food Nutr. Res., 39, 329-365. doi:10.1016/S1043-4526(08)60076-5.

Sumner, J.L., Ross, T., \& Ababouch, L. (2004). Application of risk assessment in the fish industry. Fisheries Technical paper 442. Rome: FAO.

Takahashi, H., Kimura, B., Yoshikawa, M., \& Fujii, T. (2003). Cloning and sequencing of the histidine decarboxylase genes of gram-negative, histamineproducing bacteria and their application in detection and identification of these organisms in fish. Appl. Environ. Microbiol., 69(5), 2568-2579. doi:10.1128/ AEM.69.5.2568-2579.2003.

Taylor, S.L., Guthertz, L.S., Leatherwood, M., \& Lieber, E.R. (1979). Histamine production by Klebsiella pneumoniae and an incident of scombroid fish poisoning. Appl. Environ. Microbiol., 37(2), 274-8.

Taylor, S.L. \& Woychik, N.A. (1982). Simple medium for assessing quantitative production of histamine by Enterobacteriaceae. J. Food Prot., 45, 747-751.

Torres, S., Roeckel, M., \& Cristina, M. M. (2002). Histamine formation by Morganella morganii isolated from Trachurus murphii (Chilean Mackarel). Lat. Am. Appl. Res., 32, 209-214.

Trevisani, M., Cecchini, M., Fedrizzi, G., Corradini, A., Mancusi, R., \& Tothill, I. E. (2019). Biosensing the histamin producing potential of bacteria in tuna. Front. Microbiol., 1844(10), 1-11.

Wang, D., Yamaki, S., Kawai, Y., \& Yamazaki, K. (2020). Histamine production behaviors of a psychrotolerant histamine producer, Morganella psychrotolerans, in various environmental conditions. Curr. Microbiol., 77, 460-467. 